of varices has been a successful temporary measure which may allow the patient to grow before definitive surgery is carried out.

The technique was first described by Lunderquist and Vang in 1974, ${ }^{6}$ and has been used quite extensively in adults, but to our knowledge this is the youngest child to be successfully managed in this way.

We thank Dr W S Uttley for permission to report this case, and $\mathrm{Dr} \mathrm{N}$ Finlayson for advice on management.

\section{References}

1 Rall J E, Odel H M. Congenital polycystic disease of the kidney: review of the literature and data on 207 cases. Am J Med Sci 1949; 218: 399-407.
2 Bradford W D, Bradford J W, Porter F S, Sidbury J B, Jr. Cystic disease of liver and kidney with portal hypertension: a cause of sudden unexpected hematemesis. Clin Pediatr (Phila) 1968; 7 : 299-306.

3 Parker R G F. Fibrosis of the liver as a congenital anomaly. J Pathol Bacteriol 1956; 71 : 359-68.

4 Kerr D N S, Harrison C V, Sherlock S, Walker R M. Congenital hepatic fibrosis. $Q J$ Med $1961 ; 30: 91-117$.

5 Lebrec D, Nouel O, Corbic M, Benhamou J P. Propranolol-a medical treatment for portal hypertension? Lancet 1980; ii: 180-2.

${ }^{6}$ Lunderquist A, Vang J. Transhepatic catheterization and obliteration of the coronary vein in patients with portal hypertension and esophageal varices. $N$ Engl J Med 1974; 291: 646-9.

Correspondence to Dr I Laing, Royal Hospital for Sick Children, Sciennes Road, Edinburgh EH9 1LF.

Received 28 May 1981

\title{
Benign paroxysmal torticollis in infancy
}

\section{THIERRY DEONNA AND DOROTHEA MARTIN}

Médecin-associé, Service de Pédiatrie (Unité de Neuropédiatrie), CHUV, Lausanne, and Basler Kinderspital (Neurologische Abteilung), Basel, Switzerland

SUMMARY Of 5 infants with benign paroxysmal torticollis, 3 had symptoms of infantile migraine at the same time.

Paroxysmal torticollis (PT) in infancy is a self limited and benign entity, and was first described by Snyder in $1969 .{ }^{1}$ It is characterised by recurrent episodes of ead tilt (Figure), sometimes accompanied by vomiting, pallor, agitation, and ataxia which $\vec{\bullet}$ subside spontaneously within a few hours or day $\stackrel{\infty}{-}$ and entirely disappear within a matter of months oㅡ. years. It is not widely known and is rarely reported although diagnostic problems with more serious causes of abnormal head and trunk posture or intermittent dysequilibrium in young children are encountered.

Recent observations of familial occurrence of
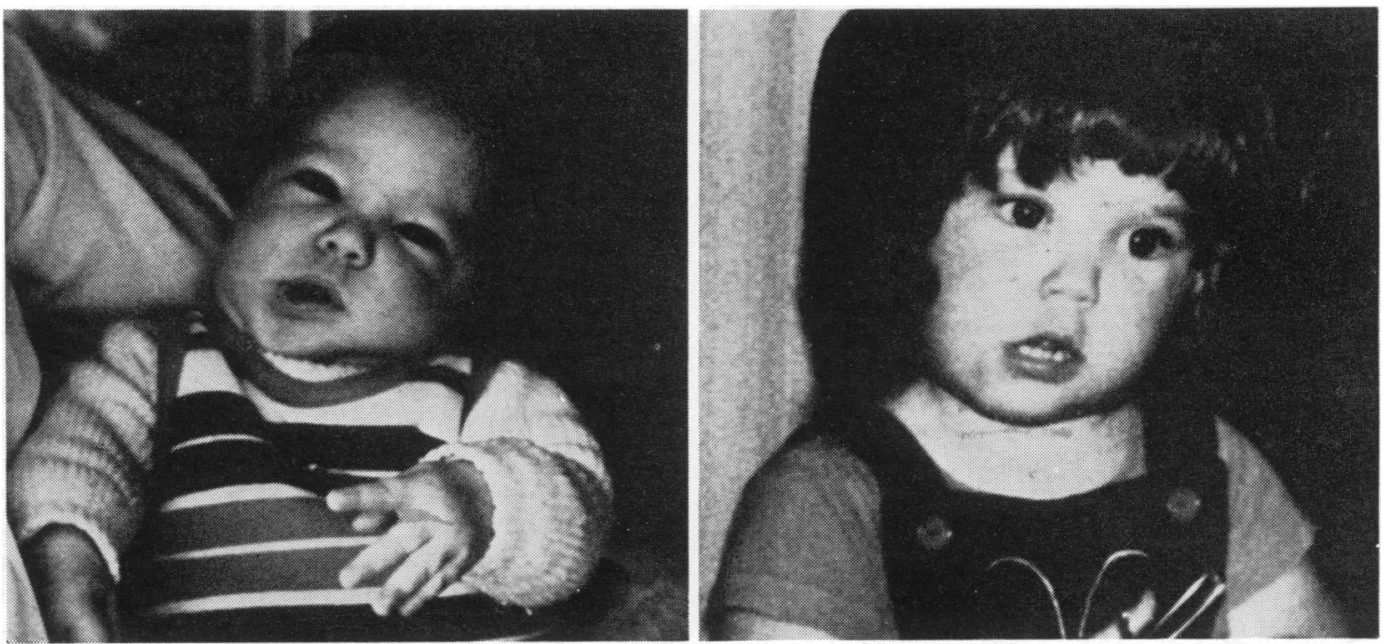

Figure (Case 5.) Head tilt in benign paroxysmal torticollis at ages 4 and 18 months. 
Table Benign paroxysmal torticollis in infancy

\begin{tabular}{|c|c|c|c|c|c|c|c|c|}
\hline Cases & $\begin{array}{l}\text { Age at onset } \\
\text { and duration } \\
\text { of follow-up }\end{array}$ & $\begin{array}{l}\text { Duration and } \\
\text { frequency of } \\
\text { attacks }\end{array}$ & $\begin{array}{l}\text { Behaviour and } \\
\text { symptoms } \\
\text { during attacks }\end{array}$ & $\begin{array}{l}\text { Precipitating } \\
\text { factors }\end{array}$ & Special tests & $\begin{array}{l}\text { Family history } \\
\text { of PT or } \\
\text { migraine }\end{array}$ & $\begin{array}{l}\text { Development of } \\
\text { symptoms with } \\
\text { time }\end{array}$ & $\begin{array}{l}\text { Migraine } \\
\text { at } \\
\text { follow-up }\end{array}$ \\
\hline $1(F)$ & $\begin{array}{l}7 \text { months } \\
3 \frac{1}{2} \text { years }\end{array}$ & $\begin{array}{l}2-3 \text { days } \\
10 \text { per year }\end{array}$ & $\begin{array}{l}\text { Vomiting, } \\
\text { appears sick }\end{array}$ & - & $\begin{array}{l}\text { EEG: normal } \\
\text { vestibular } \\
\text { function: } \\
\text { rotation test, } \\
\text { caloric test: } \\
\text { normal }\end{array}$ & $\begin{array}{l}\text { Migraine } \\
\text { (mother) }\end{array}$ & $\begin{array}{l}\text { During second } \\
\text { year crying, } \\
\text { photophobia, } \\
\text { headache, } \\
\text { unsteadiness } \\
\text { of gait, } \\
\text { vomiting } \\
\text { followed by } \\
\text { sleep }\end{array}$ & Probable \\
\hline $2(\mathrm{M})$ & $\begin{array}{l}3 \text { months } \\
4 \text { years }\end{array}$ & $\begin{array}{l}1-5 \text { days } \\
1 \text { per month }\end{array}$ & $\begin{array}{l}\text { Abnormal } \\
\text { trunk posture }\end{array}$ & $\begin{array}{l}\text { Sometimes } \\
\text { after febrile } \\
\text { illness }\end{array}$ & $\begin{array}{l}\text { EEG: normal } \\
\text { rotation test: } \\
\text { normal }\end{array}$ & $\begin{array}{c}\text { Sister had PT } \\
\text { with ataxia } \\
\text { until age } 3 \\
\text { years }\end{array}$ & $\begin{array}{l}\text { Third year, every } \\
2-3 \text { months } \\
\text { From } 2 \text { years: } \\
\text { unsteadiness of } \\
\text { gait fall to side } \\
\text { of head tilt, } \\
\text { pallor, vomiting. } \\
\text { No attacks } \\
\text { after } 2 \frac{1}{2} \text { years }\end{array}$ & - \\
\hline $3(F)$ & $\begin{array}{l}1 \text { year } \\
4 \text { years }\end{array}$ & $\begin{array}{l}1-8 \text { hours } \\
1 \text { or } 2 \text { per } \\
\text { month }\end{array}$ & Pale, apathetic & $\begin{array}{l}\text { Twice after } \\
\text { rotation of } \\
\text { child }\end{array}$ & $\begin{array}{l}\text { EEG: normal } \\
\text { rotation and } \\
\text { caloric: normal } \\
\text { CT: normal }\end{array}$ & Adopted child & $\begin{array}{l}\text { Headache, } \\
\text { drowsiness. } \\
\text { Still has attacks } \\
\text { of migraine } \\
\text { with ataxia }\end{array}$ & 一 \\
\hline $4(M)$ & $\begin{array}{l}9 \text { months } \\
8 \text { years }\end{array}$ & $\begin{array}{l}\text { 2-3 days } \\
1 \text { every one or } \\
\text { two months }\end{array}$ & $\begin{array}{l}\text { Vomiting, } \\
\text { unsteadiness } \\
\text { of gait, } \\
\text { wants to be } \\
\text { left alone }\end{array}$ & On walking & $\begin{array}{l}\text { EEG: normal } \\
\text { Audiometry } \\
\text { caloric test: } \\
\text { normal both } \\
\text { between and } \\
\text { during attacks }\end{array}$ & $\begin{array}{l}\text { Migraine } \\
\text { (mother) }\end{array}$ & $\begin{array}{l}\text { Decreased } \\
\text { frequency of } \\
\text { attacks } \\
\text { replaced by } \\
\text { attacks of severe } \\
\text { headache, pallor } \\
\text { vomiting, and } \\
\text { photophobia } \\
\text { with dis- } \\
\text { appearance of } \\
\text { torticollis and } \\
\text { ataxia }\end{array}$ & $\begin{array}{l}\text { Typical } \\
\text { migraine } \\
\text { r, }\end{array}$ \\
\hline $5(F)$ & $\begin{array}{l}2 \text { months } \\
3 \frac{1}{2} \text { years }\end{array}$ & $\begin{array}{l}\text { 1-2 weeks } \\
\text { 'Frequent' }\end{array}$ & $\begin{array}{l}\text { At times unwell } \\
\text { during attack: } \\
\text { head tilt to } \\
\text { left, broad- } \\
\text { based gait, } \\
\text { tendency to } \\
\text { fall to left }\end{array}$ & 一 & 一 & $\begin{array}{l}\text { Migraine } \\
\text { (mother) }\end{array}$ & $\begin{array}{l}\text { No attacks after } \\
\text { age } 2 \frac{1}{2} \text { years }\end{array}$ & - \\
\hline
\end{tabular}

PT, ${ }^{3}$ and a personal study of 5 patients, 3 of whom also presented with clinical features of infantile migraine, prompted us to report our experience with this peculiar disorder and to review the reported cases. $^{2-5}$

\section{Case reports}

The principal clinical features in our 5 patients are shown in the Table. We paid particular attention to each child's symptoms during initial and subsequent attacks and to the family history. The findings are compared with those of the other reported cases.

\section{Discussion}

Although torticollis is present in many types of illness in children and can result from several different mechanisms the circumstances in which it occurred here seem unique.
The early onset in the first months of life, the very frequent and often strikingly regular recurrence, ${ }^{3}$ and the tendency to remit spontaneously and to disappear entirely after a few months or years of life make it unlike any other known form of intermittent torticollis. Such attacks occur quite often initially (once or twice a month), last a few hours or days, and gradually disappear or recur after a long interval free of symptoms, eventually to stop completely. In our cases, these attacks stopped when two of the children were aged between $2 \frac{1}{2}$ and 3 years (Cases 2 and 5), but in two others they were replaced by episodes of typical migraine.

During the attacks, the head is tilted to one side (rarely always to the same side) and at times is slightly rotated. ${ }^{5}$ Some children resent head straightening, appear very unhappy at this manoeuvre, and immediately tilt their head back again. ${ }^{3}$ This was observed in only 3 of our patients. Chutorian ${ }^{4}$ reported briefly on 5 children with a 
syndrome identical with that described by Snyder, ${ }^{1}$ but in addition he mentioned retrocollis in 2 children and a trunkal postural aberration during the attacks in 4 children. The trunkal posture was also observed by Sanner and Bergström ${ }^{3}$ and was present in our Case 2. Some children with PT do not appear sick or distressed during the attacks. However, a number of associated clinical symptoms, insisted upon by Snyder ${ }^{1}$ and evident in most of our cases, is often seen. Such symptoms begin either during the initial attack or during the course of subsequent ones. Pallor, irritability, vomiting, and a general malaise have been recorded. Unsteadiness of gait was present in all our patients from the time they started to walk; this was a major complaint in one child (Case 4), but was less evident although still clearly present in the others in whom there was a tendency to veer to the side of the head tilt. Nystagmus to the left was noted during an attack in one child (Case 4). The children generally wake up in the morning with the head tilt and no specific precipitating factors have been described. Apart from abnormal head posture and instability of gait, the general physical and neurological examinations are normal. Electroencephalograms (both during attacks and between them) and neuroradiological examinations are normal. Results of auditory and vestibular function are conflicting.

Snyder found that 'ice water applied to the ear canal failed to produce nystagmus' in 9 of his 12 patients ( 6 tested during infancy and 6 tested later in childhood). Seven cases tested by audiometry in later life had 'diminished hearing'. Our Case 4 had a normal audiogram, and normal reactions to rotational and caloric testing under electronystagmographic control. Sanner found no evidence of peripheral vestibular disturbance between attacks nor was there such evidence during an acute attack. Lipson and Robertson's case $1^{2}$ also had normal water caloric testing during an attack.

We found a similar disorder in the sibling of one of our patients, a positive history of migraine (maternal) in 3 cases, and clinical features of typical childhood migraine during some attacks or at follow-up in 2 cases. Familial occurrence of PT has been reported in 2 siblings. ${ }^{2}$ The father of Sanner and Bergström's case 1 had also suffered from PT in infancy. ${ }^{3}$ Four of the original cases of Snyder have now developed benign paroxysmal vertigo. ${ }^{6}$ We have not seen this nor has it been reported by others.

Our oldest child (Case 4) developed classical migraine and 2 others (Cases 1 and 3) complained of headaches with each attack of torticollis as soon as they were old enough to express themselves.

Despite some minor differences in symptoms and course, the children described here share many features in common with those reported in the literature; this seems to confirm Snyder's observation of a separate and new clinical syndrome. The recurring abnormality of head posture is most probably a compensatory torticollis for a functional vestibular disturbance. This is suggested by many aspects of the syndrome. The associated pallor, vomiting, unsteadiness of gait with a tendency to veer to one side, and at times nystagmus, all favour this possibility. Snyder ${ }^{1}$ postulated a peripheral vestibular disorder (a possible form of labyrinthitis) because of the lack of vestibular responses to caloric testing in 9 of his patients, with decreased hearing in some of them. We, like Sanner and Bergström, ${ }^{3}$ have found normal vestibular responses with electronystagmographic control both between attacks and during them.

No abnormality of hearing was noted in their cases or in ours. As Sanner and Bergström ${ }^{3}$ stated there is no proof of a peripheral vestibular disorder in this syndrome, and a paroxysmal dysfunction of central vestibular structures or their connections seems more probable. The positive family history of PT recently reported, the family history of PT and migraine in 3 of our cases, the concurrence of typical migrainous symptoms associated with torticollis in our Cases 1 and 3 and the fact that Case 4 later developed classical migraine are circumstantias arguments for a migrainous aetiology in a number ob̂. instances. A transient vascular disturbance in the brain stem territory, as in basilar migraine might be responsible. $^{37}$ Although torticollis has not been reported in cases of basilar migraine in children, ${ }^{3}$ it is possible (as suggested by Sanner and Bergström) ${ }^{3}$ that the manifestation of the same basic disorder at an earlier age has a different impact on immature postural reflex mechanisms. On the other hand, migraine has also been implicated in the aetiology of some cases of benign paroxysmal vertigo ${ }^{8}$ which did in fact follow PT in 4 cases of Dunn and Snyder. ${ }^{6}$ A family history of PT and migraine should be sought and such children should be followed up and reported for a long period.

\section{References}

1 Snyder C. Paroxysmal torticollis in infancy: a possible form of labyrinthitis. Am J Dis Child 1969; 117: 458-60.

2 Lipson E H, Robertson W C, Jr. Paroxysmal torticollis of infancy: familial occurrence. Am J Dis Child 1978; 132: 422-3.

3 Sanner G, Bergström B. Benign paroxysmal torticollis in infancy. Acta Paediatr Scand 1979; 68: 219-23.

4 Chutorian A M. Benign paroxysmal torticollis, tortipelvis, and retrocollis in infancy (abstract). Neurology 1974; 24: 366-7. 
5 Gourley 1 M. Paroxysmal torticollis in infancy. Can Med Assoc J 1971; 105: 504-5.

- Dunn D W, Snyder C. Benign paroxysmal vertigo of childhood. Am J Dis Child 1976; 130: 1099-100.

7 Deonna $T$. Le problème neurologique de la migraine accompagnée chez l'enfant. Pediatrie 1977; 32: 119-27.
- Fenichel G M. Migraine as a cause of benign paroxysmal vertigo in childhood. J Pediatr $1967 ; 71: 114-5$.

Correspondence to $\operatorname{Dr} T$ Deonna, Service de Pediatrie, CHUV, 1011 Lausanne, Switzerland.

Received 23 June 1981

\title{
Postural deformities in congenital nephrotic syndrome
}

\author{
G MORGAN, R J POSTLETHWAITE, M LENDON, I B HOUSTON, AND J M SAVAGE
}

Royal Manchester Children's Hospital, Manchester

SUMMARY Six successive cases of congenital nephrotic syndrome are described. Each one showed flexion deformities of the knees and hips, widely open anterior and posterior fontanelles, and wide separation of the skull sutures. These abnormalities were present not only in cases in which the renal histology was of the microcystic Finnish type of congenital nephrotic syndrome, but also in those in which the histological picture was one of the variants associated with congenital nephrotic syndrome. It is suggested that such abnormalities are postural deformities, possibly produced by the large placenta.

In congenital nephrotic syndrome (CNS) heavy proteinuria and hypoalbuminaemia are present at birth. Affected babies may be hydropic, but more commonly oedema only develops in the first few days of life. Occasionally, the appearance of oedema may be delayed for weeks or months. CNS is generally familial and idiopathic, but may be secondary either to infection or to renal vein thrombosis although this is rare. ${ }^{1}$

The Finnish type of CNS is inherited as an autosomal recessive. ${ }^{1}$ In this syndrome the placenta is always large, generally at least $25 \%$ of the birthweight. Preterm delivery and birth asphyxia are common, and the baby is usually of low birthweight. Typically, the baby has a small, low-bridged nose, the anterior and posterior fontanelles are widely open, and the skull sutures widely separated. Calcaneovalgus deformities of the ankles are common. ${ }^{1}$ Other histological types of congenital and familial nephrotic syndrome occur. The two most common variants are diffuse mesangial sclerosis and focal glomerular sclerosis. ${ }^{1}$

The 6 patients with CNS described in this report showed all these abnormalities and they had other skeletal and articular abnormalities too. Two of them did not have the Finnish type of CNS.

\section{Case reports}

Details of the 6 cases are given in the Table. In 4 cases the placental weight was recorded and was between 40 and $52 \%$ of the birthweight, in a fifth case the placenta had been noted to be 'very large'. Each baby developed oedema within one week of birth. The diagnosis of nephrotic syndrome was confirmed by demonstrating hypoalbuminaemia (serum albumin $8-20 \mathrm{~g} / \mathrm{l}$ ) and heavy proteinuria (urine protein $80-180 \mathrm{mg} / \mathrm{h}$ per $\mathrm{m}^{2}$ ).

Large anterior and posterior fontanelles with widely separated sutures were present in all 6 patients, as were flexion deformities of the hips and knees

Table Summary of patients

\begin{tabular}{|c|c|c|c|c|c|c|}
\hline & \multicolumn{6}{|l|}{ Case } \\
\hline & 1 & 2 & 3 & 4 & 5 & 6 \\
\hline Histological type & Finnish & Finnish & Finnish & Finnish & $\begin{array}{l}\text { Diffuse } \\
\text { mesangial } \\
\text { sclerosis }\end{array}$ & $\begin{array}{l}\text { Focal } \\
\text { segmental } \\
\text { sclerosis }\end{array}$ \\
\hline \multicolumn{7}{|l|}{ Placental weight } \\
\hline $\begin{array}{l}\text { (\% of birthweight) } \\
\text { Large fontanelles and wide sutures }\end{array}$ & $\begin{array}{r}47 \\
+\end{array}$ & $\begin{array}{l}40 \\
+\end{array}$ & $\begin{array}{l}\text { Not recorded } \\
+\end{array}$ & $\begin{array}{l}\text { Very large } \\
+\end{array}$ & $\begin{array}{l}\text { Not recorded } \\
+\end{array}$ & $\begin{array}{c}52 \\
+\end{array}$ \\
\hline Talipes calcaneovalgus & + & + & + & - & - & - \\
\hline \multicolumn{7}{|l|}{ Flexion deformities: } \\
\hline Hips & + & + & + & + & + & + \\
\hline Knees & + & + & + & + & + & + \\
\hline Elbows & + & + & - & + & + & + \\
\hline Single palmar crease & + & - & - & - & - & + \\
\hline High arched palate & + & - & - & - & + & + \\
\hline Arachnodactyly & + & - & - & - & + & + \\
\hline
\end{tabular}

